\title{
Effect of Shodhana and Shamana Chikitsa in Mukhadushika (Acne Vulgaris) A Case Study
}

\section{Case Study}

\section{Ekta Sharma $^{1^{*}}$, Anup Jain ${ }^{2}$, Arun Gupta $^{3}$}

1. PG Scholar, 2. Assistant Professor, 3. Professor and HOD

Department of Panchakarma, Ch. Brahm Prakash Ayurved Charak Sansthan, Khera Dabar, New Delhi. India

\begin{abstract}
Acne vulgaris is a chronic disease that occurs in young adults when hair follicles are clogged with dead skin cells and oil from the skin. It is characterized by both inflammatory (papules, pustules and nodules) and noninflammatory (Comedones, open and closed) lesions.In Ayurvedic classics, in the context of Kshudra Rogas, it is mentioned that Mukhadushika occurs in yuvavastha and its signs and symptoms are similar to that of Acne vulgaris. It is due to vitiation of Vata, Kapha and Rakta having the Shalmali thorn like thick or hard painful eruptions which are impregnated with Meda. We hereby report a case of acne vulgaris which was treated under an allopathic physician with oral and topical antibiotics and found no relief so she came to Panchakarma OPD at Ch. Brahm Prakash Ayurved Charak Sansthan. According to chronicity and severity of disease, Shodhana Chikitsa and Shamana chikitsa was given. Vamana and Virechana karma (Shodhana Chikitsa) along with the topical application of lodhradi lepa and internal administration of Brihat Manjisthadi Kwath (Shamana Chikitsa) was administered for a period of 1month. Substantial clinical improvement was observed. During treatment, all the signs and symptoms of the patient were reduced.
\end{abstract}

Keywords: Mukhadushika, Acne vulgar is, Shodhana Chikitsa, Shamana Chikitsa.

\section{Introduction}

Acne vulgaris is one of the most common dermatologic condition that affects nearly everyone at some point in their lifetime. Once thought as a condition only affecting teenagers, prevalence in adulthood has been increasing, especially in women 25 years of age and older(1).It appears earlier in girls, but more boys are affected during the adolescence years; the average age for the onset of acne is 11 years in girls, affecting up to $82 \%$, and 12 years in boys, affecting up to $95 \%$. Recently, there has been a rise in the appearance of acne in those as young as 8 or 9 years of age. This increase at such a young age has been attributed to the decreasing age of puberty onset (2).It is characterized by the presence of lesions most commonly on the face, neck, chest, or back. Itoccurs when pores become blocked with Sebum which is made by the sebaceous glands that helps keep hair and skin moisturized. Hormone changes during the teenage cause the body to make more of this oily substance (sebum), thus are clogging the follicles. Bacteria can get inside the follicle or oil gland and cause redness, swelling, and pus. In Ayurveda, it is described under the Mukhadushika which is a type of Kshudra Roga. It is due to vitiation of Kapha,Vata and Rakta having Shalmali thorn like eruptions on face(3). In Ayurveda, mainly two types of Chikitsa (treatments) have been

*Corresponding Author:

\section{Ekta Sharma}

PG Scholar, Department of Panchakarma,

Ch. Brahm Prakash Ayurved Charak Sansthan,

Khera Dabar, New Delhi. India

Email id: ekusharma.11.es@gmail.com used to treat Mukhadushika i.e. Shodhana (purification of body) and Shamana (conservative treatment by oral and topical medicines). In this case study, management of Mukhadushika (Acne vulgaris) has been elaborated with both Shodhana and Shamana Chikitsa.

\section{Materials and Methods}

A 19-year-old female patient visited the Panchakarma O.P.D at Ch. Brahm Prakash Ayurved Charak Sansthan, Khera Dabar, New Delhi with following complaints:

- Pidaka (Papules) on face including Medogarbhatva (filling material)

- Todavat peeda (Piercing pain)

- Daha (Burning sensation)

- Srava (Discharge)

\section{History of Present Illness}

The patient was asymptomatic 3 years back, since then she has been suffering from multiple papules, pustules with pain, itching and discharge.

\section{History of Past Illness \\ $\mathrm{H} / \mathrm{o}$ Chickenpox in childhood}
Asthavidha Pariksha-
- Nadi-Vataadhika
- Shabda-Prakrut
- Mala-Asamyaka Pravruti
- Sparsh-Snigdha
- Mutra-Prakrat
- Druk-Prakrut
- Jivhva-Saama
- Aakruti-Madhyam 
Treatment history

Patient took allopathic medicines (topical and oral) for these Complaints but could not found significant relief.

Treatment Plan

1. Shodhana Chikitsa (Vamana and Virechana).

2. Shamana Chikitsa (Brihat Manjisthadi Kwath (4) and Lodhradi Lepa (5)

\section{Medicine for Vamana:}

- Madanphala seed powder -Antarnakhamushti (dried)

- Vamanopag drug-Yashtimadhu phanta - 3 litres

- Madhu-10gm

\section{Medicine for Virechana}

Abhyadi Modaka (6) $250 \mathrm{mg}$

Medicine for oral medication

Brihat Manjisthadhi kwath 40ml BD

\section{Medicine for local application}

Lodhradi Lepa-LA
Assessment Criteria

Table 1. Ayurvedic Assessment scale (7)

\begin{tabular}{|l|l|}
\hline Kandu (Itching) \\
\hline Continuous itching & 2 \\
\hline Occasional itching & 1 \\
\hline No itching & 0 \\
\hline Vedana (Pain) & 2 \\
\hline Pain without touch & 1 \\
\hline Pain on touch & 0 \\
\hline No pain & 0 \\
\hline Vivarnta (Discoloration) \\
\hline Reddish yellow & 4 \\
\hline Reddish pink & 4 \\
\hline Reddish brown & 4 \\
\hline Red & 3 \\
\hline Black & 2 \\
\hline Black grey & 1 \\
\hline Normal & 0 \\
\hline Shotha (Inflammation) & \\
\hline $10 \mathrm{~mm}$ & 3 \\
\hline $5 \mathrm{~mm}$ & 2 \\
\hline 2mm & 1 \\
\hline No swelling & 0 \\
\hline
\end{tabular}

Table 2. Medicine and Dose Schedule

\begin{tabular}{|l|l|l|l|l|}
\hline S.No. & Procedure & Medicine & Doses & Duration \\
\hline 1. & Deepana Pachana & Chitrakadhi vati & 2 BD after meal & 3 days \\
\hline 2 & Snehapana & Panchatikta ghrita(8) & As per kostha and agni & 5 days \\
\hline 3 & Abhyanga and swedana & $\begin{array}{l}\text { Tila tail for abhyanga } \\
\text { Vashpa sweda }\end{array}$ & $\begin{array}{l}30 \text { minutes } \\
10-15 \mathrm{~min}\end{array}$ & 2 days \\
\hline 4 & Vamana karma & Vamaka yoga & As per kostha & 1 days \\
\hline 5 & Sansarjana karma & - & Pradhana shuddhi & 7 days \\
\hline 6. & Snehapana & Panchatikta ghrit & As per kostha and agni & 3 days \\
\hline 7. & Abhyanga and Swedana & Tila taila & Vashpa sweda & 3 days \\
\hline 8. & Virechana & Abhyadhi modaka & 2 Tablet & 1 days \\
\hline 9. & Sansarjana karma & - & Pradhana shuddhi & 7 days \\
\hline 10 & Shamana chikitsa & Brihat Manjisthadi kwath & $40 \mathrm{ml} \mathrm{BD}$ & 1 month \\
\cline { 3 - 4 } & & Lodhradi lepa & Local application & \\
\hline
\end{tabular}

\section{Procedure of Lepa Application}

The patient was advised to apply Lepa once in a day. It was conducted in three steps, viz-

\section{Poorva karma}

The Patient was asked to wash the face with normal water prior to application of Lepa.

\section{Pradhana karma}

Required Quantity of Lodhradi churna was taken and normal water added in sufficient amount to convert the churna in Lepa form.
The patient was advised to apply Lepa in pratiloma gati all over the face.

The Lepa was applied with a uniform thickness of one fourth of patient's own thumb width (about $1 / 4^{\text {th }}$ of an inch).

Lepa was applied in morning / for at least 30min or until it dried.

\section{Pashchat karma}

After the drying up of the Lepa, the patient was asked to wash the face with normal water.

Patient was advised not to expose to sun during the period of treatment. 
Table 3: Changes in Signs and Symptoms before and after each Follow Up

\begin{tabular}{|l|c|c|c|c|}
\hline Signs and Symptoms & BT & AT & $\mathbf{1}^{\text {st }}$ Follow Up & II $^{\text {nd }}$ Follow up \\
\hline Kandu (Itching) & 2 & 0 & 0 & 0 \\
\hline Vedana (Pain) & 2 & 1 & 0 & 0 \\
\hline Vivarnta (Discoloration) & 4 & 2 & 1 & 0 \\
\hline Shotha (Inflammation & 3 & 1 & 0 & 0 \\
\hline
\end{tabular}

\section{Discussion}

The disease Mukhadushika is described under the head of Kshudra Roga, but it is one of the major cosmetic related problem of younger age group leading to maximum extent of Psycho-social trauma and lack of confidence regarding their personality and appearance as well. In present case study, patient got complete relief from signs and symptoms of Mukhadushika (acne vulgaris). Vamana and Virechana (Shodhana Chikitsa) showed good results along with Shamana Chikitsa. It is the prime treatment of Mukhadushika as told by Acharya Shushrut ((9), and Vagbhatta (10). It helps in elimination of kapha from the body and Samprapti Vighatana of Mukhadushika. Virechana Karma is indicated specially to subsides Pitta Dosha or Pitta Sansargaja Dosha. The purgative drugs expel the excess Pitta from the Guda marga. Property of Rakta is analogous to Pitta Dosha, therefore, Virechana is also effective in Raktaja Vikara. In Ayurvedic texts Acharya Charaka has explained Virechana, as treatment modality in Raktaja and Pittaja Vikara(11).

Table 4: Lodhradi Lepa

\begin{tabular}{|l|l|l|l|l|l|}
\hline Drug & Rasa & Guna & Veerya & Vipaka & Prabhava \\
\hline Lodhra & Kashaya & Laghu, Ruksha & Sheeta & Katu & $\begin{array}{l}\text { Shonita sthapana, sandhaniya, } \\
\text { Kapha pitta hara }\end{array}$ \\
\hline Vacha & Katu Tikta & Laghu,Tikshna & Ushna & Katu & $\begin{array}{l}\text { Lekhana, vatakapha hara, } \\
\text { sanjyasthapana }\end{array}$ \\
\hline Dhanyaka & $\begin{array}{l}\text { Kashaya, Tikta, } \\
\text { Madhura, Katu }\end{array}$ & Laghu, Snigdha & Ushna & Madhura & $\begin{array}{l}\text { Trishna nigrahana, mutrala, } \\
\text { tridoshahara }\end{array}$ \\
\hline
\end{tabular}

\section{Probable Mode of Action of Lodhradi Lepa}

Lodhradi Lepa was selected for external application. It is described in Sharangdhara Samhita. It contains 3 drugs namely Lodhra, Vacha and Dhanyaka. All the drugs except Lodhra are ushna veerya so they are Vata kapha shamaka and sheeta veerya of lodhra pacifies the dushita Rakta. Vacha has lekhana property so it helps in Subsiding Medogarbha pidika. Thus, the combination of drugs helps in reversing the pathogenesis of Mukhadushika (Acne Vulgaris).

\section{Probable Mode of action of Brihat Manjisthadi Kwath}

The ingredients of Brihat Manjisthadi kwath are Manjistha, Musta, Kutaja, Guduchi, Kustha, Nagara,Bharangi,Vacha,Nimba,Haridra,Daruharidra, Triphala,Patola, Katuka,Khadira, Chandana,Trivrit,Bak uchi,Karanja,Ativisha,Murva,Vidanga, Chitraka,Shatav ari,Trayamana,Indervaruni,Sariva,Inderyava, Vasa,Mah adaru,Patha. Most of the drugs are tridoshaghna or kapha pittahara property by virtue of Tikta,Katu,Kashaya Rasa;Laghu, Ruksha Guna, and Ushna Veerya;Katu Vipaka. Manjistha is Varnya and Rakta prasadana, Nimba is kandughna,Haridra is Kusthaghna,Vacha is Sroto shodhana.All these drugs perform the therapeutic pharmacological action on the basis of innate qualities i.e. Rasa,Guna,Veerya,Vipaka and Prabhava altogether and follow the samprapti Vighatana Chikitsa Siddhanta.

\section{Conclusion}

Mukhadushika is a Kapha- Vata- Rakta Pradhana Vyadhi which has clinical features similar to Acne vulgaris. Vamana andVirechana as shodhana chikitsa and Lodhradi lepa, brihat manjisthadi kwath as shamana chikitsa, when given together prove quite effective in managing the patients of Mukhadushika. It can be concluded that the patients of Mukhadushika can be managed effectively by Ayurveda without any fear of side effects.

\section{References}

1. Decker A, Graber EM. Over-the-counter acne treatments: a review. J Clin Aesthetic Dermatol. 2012;5(5):32-40.

2. Knutsen-Larson S, Dawson AL, Dunnick CA, Dellavalle RP. Acne vulgaris: pathogenesis, treatment, and needs assessment. Dermatol Clin. 2012;30(1):99-106.

3. Sushruta, Sushruta Samhita, Nidana Sthana,13/38, Ayureda tatva sandipika, Hindi Commentary by Kaviraja Ambika datta Shastri, Reprint edition 2009, Chaukambha Sanskrit Sansthan, Varanasi, Page 372

4. Brahmanand tripathi, Sharanghdhara Samhita Deepika hindi Commentary, Madhyam khand, $2^{\text {nd }}$ chapter, Kwath Kalpana, 4 th edition, Chaukambha Orientalia, Varanasi(India )-2005, Page 154

5. Brahmanand tripathi, Sharanghdhara Samhita, Deepika, hindi Commentary, Uttarakhand, 
$11^{\text {th }}$ chapter, Lepa prakarana, $4^{\text {th }}$ edition, Chaukambha Orientalia, Varanasi(India )-2005, Page 392

6. Brahmanand tripathi, Sharanghdhara Samhita, Deepika hindi Commentary, Uttara khand, $4^{\text {th }}$ chapter, Modaka Kalpana, $4^{\text {th }}$ dition, Chaukambha Orientalia, Varanasi(India )-2005, Page206

7. Rathod S, Nesari T:The Study of Shalmali with special reference to its efficacy of Mukhadushika, 2001 [wipps, vol 6, issue 3, 874-895]

8. Brahmanand tripathi, Sharanghdhara Samhita, Deepika, hindi Commentary, Madhyam khand, $9^{\text {th }}$ chapter, snehapaka vidhi, $4^{\text {th }}$ edition, Chaukambha Orientalia, Varanasi(India )-2005, Page 231
9. Sushruta, Sushruta Samhita, Chikitsa Sthana, 20/37, Ayurveda tatva sandipika, Hindi Commentary by Kaviraja Ambika datta Shastri, Reprint edition 2009, Chaukambha Sanskrit Sansthan, Varanasi, Page 118

10. Vaghbhatta, Astanga hridaya, Uttara khanda, 32/3, Nirmala, Hindi Commentary by Brahmanand tripathi, Reprint edition 2009, Chaukambha Sanskrit Pratisthan, Varanasi, Page 1119

11. Charaka, Charaka Samhita, Sutra Sthana, 24/18, Vidhyotni, Hindi Commentary by Kashinath Shastri, Reprint Edition 2011, Chaukambha Sanskrit Pratisthan, Varanasi, Page 302. 